Review

\title{
Port City Sustainability: A Review of Its Research Trends
}

\author{
Ying Zheng ${ }^{1,2, *}$, Jingzhu Zhao ${ }^{3}$ and Guofan Shao ${ }^{2, *}$ \\ College of Business Administration, Fujian Jiangxia University, Fuzhou 350108, China \\ 2 Department of Forestry and Natural Resources, Purdue University, West Lafayette, IN 47907, USA \\ 3 Institute of Urban Environment, Chinese Academy of Sciences, Xiamen 361021, China; jzhao@rcees.ac.cn \\ * Correspondence: zhengying@fjjxu.edu.cn (Y.Z.); shao@purdue.edu (G.S.); \\ Tel.: +86-591-23-537-993 (Y.Z.); +86-765-494-3630 (G.S.)
}

Received: 21 August 2020; Accepted: 9 October 2020; Published: 11 October 2020

check for updates

\begin{abstract}
In recent years, with the development of society, the awareness of environmental protection for people has been increasing. While ports promote the economic development and employment levels of port cities, they also have a negative impact on the environment of port cities. The sustainability of port cities is increasingly valued. Port cities face huge challenges, and their sustainability needs to be better understood. The purpose of this article is to review research on the sustainability of port cities. We used content analysis to classify and analyze the existing relevant literature, to learn about the hotspots and deficiencies of past research, and to propose future research directions. We found that port sustainability has become an increasingly important research topic during the past ten years. From the perspective of geographic research areas, European port cities are the hot spots for sustainability research. Regarding research fields, technologies, methods and measures to promote the sustainability of port cities are popular research topics. In terms of research methods, qualitative research plays an important role in the study of port city sustainability. Finally, guidance for future research on port city sustainability is proposed according to the review results.
\end{abstract}

Keywords: port city; sustainability; literature review; content analysis; sustainable development

\section{Introduction}

With the global population growth and increasingly destructive character of human activities toward the environment, sustainable development has become a global consensus. The most adopted definition of sustainability was given in the report of 'Our Common Future' for the World Commission on Environment and Development (WCED) in 1987: "Sustainable development is development that meets the needs of the present without compromising the ability of future generations to meet their own needs" [1]. Sustainable development mainly includes three components: environmental sustainability, economic sustainability and social sustainability. Its connotation emphasizes the coordinated development of the environment, economy and society, and effectively combines environmental protection and human development [2-4]. The city itself plays a key role in sustainability, because it is not only an important engine of economic growth, but also puts tremendous pressure on the environment while facing huge challenges from society [5]. With the acceleration of urbanization processes, the population of the city has exploded, and the size of the city has become larger and larger. The interactions between urban environmental, social and economic issues, and urban sustainability have attracted increasing attentions [6].

A port city is not only a center of economic activity but also an important hub of the transportation network. It combines port economy, logistics and industrial activities with the creativity of the local inhabitants [7]. A port city is usually the gathering point between import and export trade, and between 
industry and tourism. In the list of the top ten most powerful cities in the world in 2019, seven are seaport cities [8]. The port and the city are not two separate entities. Instead, the two identities are closely intertwined, and are mutually interdependent and influential [9]. Most coastal cities originated from ports, which support the development of the cities. After the Second World War, the rapid development of international trade led to the development of shipping and manufacturing in coastal areas, resulting in some large ports, which, in turn, created some large cities, such as Tokyo, Los Angeles and Singapore, etc. [10]. Many ports are located near urban centers or residential areas, and have become parts of urban systems [11]. Such a spatial intersection may bring difficulties for the construction of visually appealing urban landscapes, and may result in negative effects on people's perception of the urban environment [12].

Due to the comparative advantages of economies of scale and network economies which result in low transportation costs, about $90 \%$ of world-trade transportation is carried by the international shipping industry [13]. Maritime transportation has significant environmental advantages [14]. The port is a key node of the supply chain and the maritime transportation network [15], and a link between the maritime and land transportation chains [16,17]. Although they have a positive impact on increasing local employment opportunities and promoting local and regional economic growth, port activities impose a great negative impact on environmental pollution and ecological degradation [18,19]. At present, shipping has become one of the fastest growing sectors of greenhouse gas emissions [20]. Approximately $70 \%$ of the marine emissions occur in the coastal area around the world, and $60-90 \%$ of them occur while ships are berthing in ports [21]. Therefore, the reduction of the time span that a vessel spends in port can reduce emissions [22]. The production and operation activities of ports cause air pollution, noise, soil contamination, habitat destruction, and traffic congestion, etc., causing negative effects on ecosystems and the health of the local communities surrounding the ports [11,23-25]. As a result, there are economic and ecological conflicts between ports and the cities [7,26,27], and ports are facing increasing environmental and social pressure. Ports are closely connected with port cities, and form part of the port-city systems [28]. Due to the great impact of ports on cities, ports have become the key to the sustainable development of the entire urban system. The sustainable development of port cities requires ports to incorporate sustainability into their overall development goals and policies [9].

In recent years, as attention to the sustainability of ports and port cities is increasing, studies focused on port sustainability have gradually increased, and have appeared in some literature reviews [29-32]. As port sustainability is facing new challenges, it is important to update the literature review on the sustainability of port cities. Ports are an important source of pollution, and cities are places where people reside. While relationship between ports and cities is intricate, the sustainability of ports and port cities has increasingly aroused the worry of stakeholders such as port authorities, policy makers, users and local residents. Therefore, a timely literature review is helpful to guide the future development of this field by analyzing the research results on the sustainability of port cities published in relatively influential databases.

\section{Methods}

\subsection{Content Analysis}

Content analysis, a highly flexible research method for the analysis of text data, is used to make replicable and valid inferences from data to their context [33]. The framework of content analysis mainly comes from three aspects: the existing theories or practices, the experience or knowledge from experts, and previous research [34]. Content analysis can be converted into two levels of analysis. The first level analysis emphasizes the manifest content of texts and documents by statistical methods. The second level analysis excavates the latent content of texts and documents, explaining the underlying meaning of terms and arguments [35]. Content analysis can be used for both quantitative and qualitative research, and can be divided into quantitative content analysis and qualitative content analysis [34]. 
Since literature reviews are mainly qualitative syntheses of results, the qualitative content analysis was used in this research [35].

\subsection{Qualitative Content Analysis}

Qualitative content analysis can be achieved with three main approaches: conventional, directed, and summative. Conventional content analysis starts with observation, and the coding categories are derived from text data; directed content analysis starts with a theory, and the coding categories are derived from theory or relevant research findings; summative content analysis starts with keywords, which are derived from the interest of researchers or a review of the literature [36]. Summative content analysis is not an overall analysis of the data. Usually, the text is treated as it relates to a single word or a specific content. Data analysis starts with searches for the identified words, and calculates the word frequency counts for each identified term. Word counting is used to identify patterns in the data [36]. The process of a literature review is to define and refine parameters and keywords, to search and evaluate the literature repeatedly with keywords in order to evaluate a certain knowledge field, and to discover the knowledge gaps that need to be filled [35]. Therefore, summative content analysis was adopted in this research.

The process of qualitative content analysis can be divided into four steps: material collection, descriptive analysis, category selection, and material evaluation [35]. Subsequently, some researchers use qualitative content analysis in literature reviews to follow the four steps above [37,38]. This approach was used in the literature review in this paper.

\section{Implementation Process}

\subsection{Material Collection}

The key to material collection is to delimitate the material and to define the unit of the analysis [35].

\subsubsection{Defining Material}

(1) The type of literature: some conference papers and book chapters may lack peer reviews. In order to better demonstrate the current results of the research topic, we limited the analysis unit to peer-reviewed 'journal' articles, and excluded conference papers, book series, book chapters, commercial publications, reviews, reports, government documents, and white papers [30,37].

(2) The language of the literature: only materials in English were used.

(3) The time frame: because the concept of sustainable development was put forward in 1987, in the report 'Our Common Future' in the World Commission on Environment and Development (WCED), articles published between 1987 and 2019 were selected in this study.

(4) The database used: Scopus and the Web of Science Core Collection database were used. Scopus is currently the largest abstract and citation database in the world, providing the most comprehensive summary of global research results in the fields of science, technology, medicine, social science, and the arts and humanities, covering over 23,000 peer-reviewed journals (https://www.elsevier.com/?a=69451). The Web of Science Core Collection is among the most trusted scientific research reference indexes in the world, covering more than 250 sciences, social sciences, and arts and humanities disciplines worldwide, bringing together over 21,000 peer-reviewed, high-quality scholarly journals (https://clarivate.com/webofsciencegroup/ solutions/web-of-science-core-collection/). The limitation of Scopus is its limited access to publications prior to 1996, but the Web of Science Core Collection can make up for this deficiency [38].

(5) The retrieval method: due to the limitation of the title length, some titles may not fully explain the research content of articles, and the abstract can supplement the deficiencies in this regard, so "topic (title, abstract, keywords) retrieval" was used in this study [39]. 


\subsubsection{Defining Unit of Analysis}

This analysis consists of three steps: searching for literature with the defined keywords, eliminating the duplicate literature, and quickly checking the abstract and content of the literature in order to determine the final unit of analysis.

The theme of this study is "Port City Sustainability". In order to achieve the purpose of content analysis, we first needed to collect research on "Port City Sustainability". In order to improve search efficiency, it is critical to determine keywords that are suitable for database retrieval. The keywords in this study were mainly defined according to our research experience, including those that appeared frequently in the literature of sustainability studies of ports and port cities. Considering that the concepts of "green" and sustainable development are identified as being mutually dependant, the concept of a "green port" is developed from activities for a sustainable port, and is a reflection of a sustainable and environmental friendly port [40], and ecological protection and environmental management are important elements of sustainability $[18,26]$. After several trial-and-error retrieval attempts, the following keywords were finally determined (Table 1 ).

Table 1. The search keywords.

\begin{tabular}{cc}
\hline Number & Corresponding Keywords \\
\hline 1 & Sustainable port (seaport) city \\
2 & Port (seaport) city sustainability \\
3 & Green port (seaport) city \\
4 & Port (seaport) city ecological protection \\
5 & Port (seaport) city environmental management \\
\hline
\end{tabular}

Using the five keywords listed in Table 1, a total of 528 articles were obtained from the Scopus database. After eliminating duplicate articles, 396 articles remained. Using the same keywords, a total of 448 articles were obtained from the Web of Science Core Collection database. After eliminating duplicate articles, 332 articles were kept (Table 2). We then obtained a total of $728(396+332=728)$ articles from the two databases. Because redundant articles may be stored in the two databases, we eliminated duplicates from the 728 collected articles for the second time, and obtained 514 articles in total. Since this study only focuses on the sustainability issues of port cities related to ports and port industries, after reading and summarizing the abstracts of the 514 pieces of literature, we found that the current research fields related to this research topic were mainly focused on these aspects: the impact of ports' and cities' interactions on the sustainability of port cities, a sustainability assessment of port cities, the impact of stakeholders on the sustainability of port cities, and sustainability issues and the solutions of port cities. In order to ensure the reliability and internal validity of the study, after excluding literature for which the topic did not fit the scope of this study, the 61 most relevant pieces of literature were used in this study.

Table 2. Number of pieces of research available on the topic of "Port City Sustainability".

\begin{tabular}{ccc}
\hline Keywords/Databases & Scopus & Web of Science Core Collection \\
\hline Sustainable port (seaport) city & 194 & 187 \\
Port (seaport) city sustainability & 104 & 112 \\
Green port (seaport) city & 62 & 55 \\
Port (seaport) city ecological protection & 20 & 14 \\
Port (seaport) city environmental management & 148 & 80 \\
Total & 528 & 448 \\
Duplicate article & 132 & 116 \\
Total after first eliminating duplicates & 396 & 332 \\
\hline
\end{tabular}




\subsection{Descriptive Analysis}

The purpose of descriptive analysis is to assess the formal characteristics of the material, and to provide a background for subsequent analysis. This analysis mainly provides basic information about the unit of analysis, such as the distribution of publications over a time period from various source journals [35].

\subsubsection{Publishing Time}

Among the 61 articles used in the literature review, only one article was published before 2000, and 58 articles were published during the past decade (Figure 1). This may be because, with the understanding of ports and port activities, people have gradually realized that ports are an important source of pollution, and port production and operation activities have caused environmental pollution and ecological damage. In the past ten years, the concept of energy conservation, environmental protection, and sustainable development has become the consensus of global economic development. With the increasing awareness of environmental protection, people are paying more and more attention to the impacts of ports on the environment.

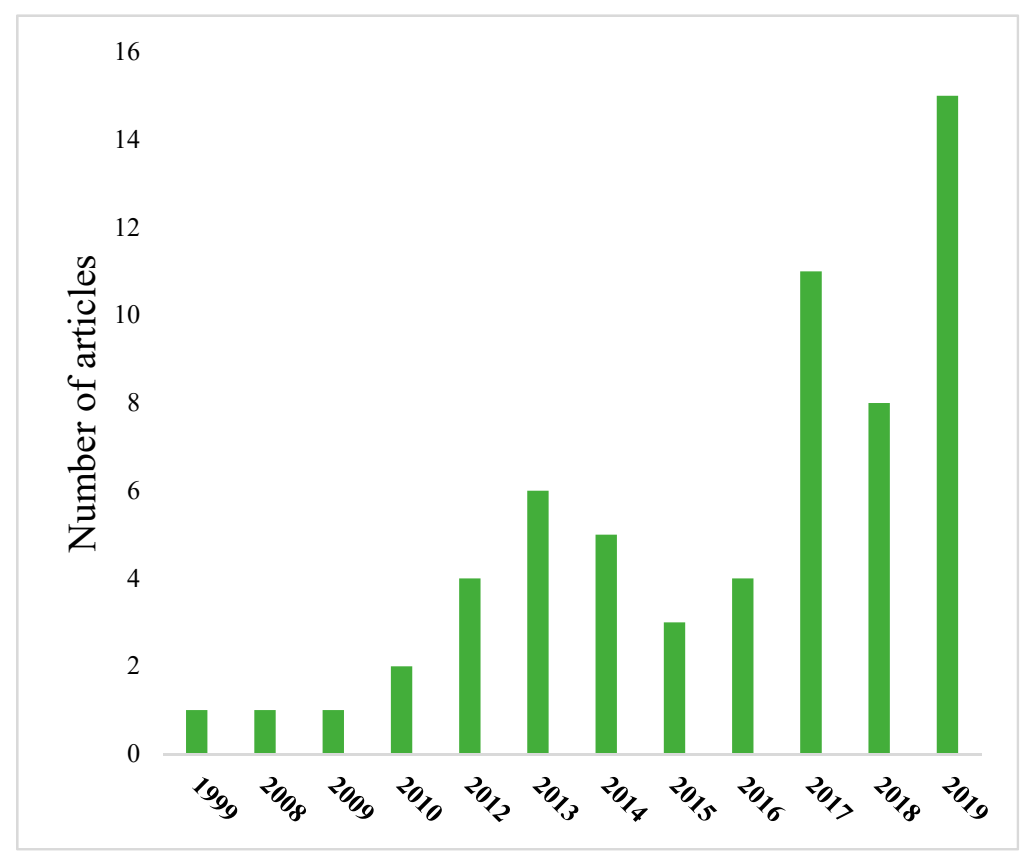

Figure 1. Number of articles published per year between 1987 and 2019.

\subsubsection{Source Journals}

Of the 61 articles, the journal with the most pieces of literature is 'Sustainability', which covers 18 articles, followed by 'Transportation Research Part D: Transport and Environment', with three articles (Table 3).

Table 3. The top six source journals with the most literature selected.

\begin{tabular}{ccc}
\hline Source Journal & Articles (Totally Selected 61 Articles) & Number of Articles \\
\hline & Kourtit and Nijkamp (2013), Fusco Girard (2013), Lam and \\
& Yap (2019), Liu et al. (2019), De Rosa and Di Palma (2013), \\
& Attardi et al. (2012), Li et al. (2019), van Timmeren et al. \\
(2012), Mrak(2013), Li et al. (2016), Zanetti et al. (2016), & 18 \\
Sustainability & Zheng,Wang et al. (2017), Zheng, Yang et al. (2017), \\
& Fusco Girard and Nocca (2019), Gravagnuolo et al. (2019), \\
& Ito et al. (2019), Lee et al. (2019), Williams (2019) \\
\hline
\end{tabular}


Table 3. Cont.

\begin{tabular}{ccc}
\hline Source Journal & Articles (Totally Selected 61 Articles) & Number of Articles \\
\hline $\begin{array}{c}\text { Transportation Research Part D: } \\
\text { Transport and Environment }\end{array}$ & $\begin{array}{c}\text { Schipper et al. (2017), Tang et al. (2017), } \\
\text { Merico et al. (2019) }\end{array}$ & 3 \\
\hline $\begin{array}{c}\text { European Journal of Sustainable } \\
\text { Development }\end{array}$ & Ezzat (2016), Mammadova(2017) & 2 \\
\hline Journal of Cleaner Production & Frantzeskaki et al. (2014), Holmstedt et al. (2017) & 2 \\
\hline $\begin{array}{c}\text { International Journal of Global } \\
\text { Environmental Issues }\end{array}$ & Hein (2014), Ravetz (2014) & 2 \\
\hline Journal of Industrial Ecology & Shahrokni et al. (2015), Voskamp et al. (2017) & 2 \\
\hline
\end{tabular}

\subsection{Category Selection and Material Evaluation}

Category selection means the selection of the structural dimensions and related analytic categories to apply to the collected material. Material evaluation means the analysis of the material according to dimensions, where abstract, explanative and structured means are used to understand and explain the text [35]. The research areas, research problems and research methods of articles were selected for classification and analysis in this study [30,31,41].

\subsubsection{Geography of Case Studies}

Among the 61 articles, 33 of them were published for European port cities, 20 for Asian port cities, nine for American port cities, and five for African port cities. Three articles were related to the port cities of Oceania (Table 4). More than $50 \%$ of the areas of the case studies were related to European port cities, which may be due to the significant share of European researchers in the port economics field. The port city that appeared the most was Rotterdam in the Netherlands, which reached nine times; followed by Amsterdam in the Netherlands, which appeared five times; followed by Antwerp in Belgium, Stockholm in Sweden, Shanghai in China, and Hamburg in Germany, which appeared four times each. Los Angeles in the United States (USA), London in the United Kingdom (UK) and Naples in Italy appeared three times. The reason may be that these ports are geographically superior; that they are global port hubs, or historical and cultural ports; and that they are the concern of many researchers.

Table 4. Classification according to the geographical distribution of the port cities in the case studies.

\begin{tabular}{ccc}
\hline Port City (Country or Region) & Articles (Totally Selected 61 Articles) & Frequency (\%) \\
\hline Europe & 33 (54\%) & 2 \\
\hline Amsterdam (Netherlands) & $\begin{array}{c}\text { Kourtit and Nijkamp (2013), } \\
\text { Voskamp et al. (2017) }\end{array}$ & 5 \\
Rotterdam (Netherlands) & $\begin{array}{c}\text { Meyer et al. (2012), Frantzeskaki et al. } \\
\text { (2014), van Tuijl and van den Berg (2016), } \\
\text { Dircke and Molenaar (2010), } \\
\text { Van Timmeren et al. (2012) }\end{array}$ & 3 \\
\hline Naples (Italy) & $\begin{array}{c}\text { Cavallo et al. (2015), Pugliano et al. (2018), } \\
\text { De Rosa and Di Palma (2013) }\end{array}$ & 1 \\
\hline Brindisi (Italy) & Attardi et al. (2012) & 1 \\
\hline Bari (Italy) & Merico et al. (2019) & 1 \\
\hline Venice (Italy) & Sheeran and Pilato (2017) & \\
\hline $\begin{array}{c}\text { London/Glasgow (UK), Rotterdam/Amsterdam } \\
\text { (The Netherlands), Paris/Marseille (France), } \\
\begin{array}{c}\text { Antwerp/Brussels (Belgium), Maribor/Luibljana } \\
\text { (Slovenia), Praga (Czech Republic), Kalundborg } \\
\text { (Denmark), Göteborg/Malmö (Sweden) }\end{array}\end{array}$ & Fusco Girard and Nocca (2019) & \\
\hline
\end{tabular}


Table 4. Cont.

\begin{tabular}{|c|c|c|}
\hline Port City (Country or Region) & Articles (Totally Selected 61 Articles) & Frequency $(\%)$ \\
\hline Liverpool, Glasgow (UK) & Ravetz (2014) & 1 \\
\hline $\begin{array}{l}\text { Amsterdam/Rotterdam (Netherlands), London (UK), } \\
\text { Antwerp (Belgium), Hamburg (Germany), Marseille } \\
\text { (France), Lisbon/Porto (Portugal) }\end{array}$ & Gravagnuolo et al. (2019) & 1 \\
\hline Copenhagen (Denmark) & Karimpour et al. (2019) & 1 \\
\hline Stockholm (Sweden) & $\begin{array}{l}\text { Williams (2019), Holmstedt et al. (2017), } \\
\text { Shahrokni et al. (2015) }\end{array}$ & 3 \\
\hline Stockholm (Sweden), Amsterdam (Netherlands) & Bossuyt and Savini (2018) & 1 \\
\hline Barcelona (Spain) & Ruiz-Guerra et al. (2019) & 1 \\
\hline Alicante (Spain) & Aragonés et al. (2017) & 1 \\
\hline Piraeus (Greek) & Delitheou and Georgakopoulou (2019) & 1 \\
\hline Gdynia (Poland) & Przybyłowski (2018) & 1 \\
\hline Dublin (Ireland) & Tang et al. (2017) & 1 \\
\hline Split (Croatia) & Dundović et al. (2013) & 1 \\
\hline Rijeka (Croatia) & Mrak (2013) & 1 \\
\hline $\begin{array}{l}\text { Antwerp (Belgium), Hamburg (Germany), } \\
\text { Rotterdam (Netherlands) }\end{array}$ & Schipper et al. (2017) & 1 \\
\hline $\begin{array}{c}\text { Rotterdam (Netherlands), Hamburg (Germany), } \\
\text { Antwerp (Belgium) }\end{array}$ & Chen and Lam (2018) & 1 \\
\hline London (UK), Hamburg (Germany) & Hein (2014) & 1 \\
\hline $\begin{array}{c}\text { Barcelona/Palma de Mallorca/Malaga (Spain), } \\
\text { Venice/Civitavecchia/Genoa/Naples/Leghorn/Savona/Bari } \\
\text { (Italy), Piraeus/Corfu/Santorini/Mykonos/Katakolon (Greece) } \\
\text { Marseilles (France), Dubrovnik (Croatia), Valletta (Malta) }\end{array}$ & Rosa-Jiménez et al. (2018) & 1 \\
\hline No specified port city (UK) & Yigit and Acarkan (2018) & 1 \\
\hline Asia & & $20(33 \%)$ \\
\hline Singapore (Singapore) & Xiao and Lam (2017) & 1 \\
\hline Shanghai (China) & Li et al. (2019) & 1 \\
\hline Guangzhou/Shenzhen (China) & Lam and Yap (2019) & 1 \\
\hline Dalian et al. (China) & Liu et al. (2019) & 1 \\
\hline Ningbo (China) & $\begin{array}{l}\text { Zheng, Yang et al. (2017), Zheng, } \\
\text { Wang et al. (2017) }\end{array}$ & 2 \\
\hline Rizhao (China) & Wang et al. (2009) & 1 \\
\hline Dalian/Shanghai/Ningbo et al. (China) & Li et al. (2016) & 1 \\
\hline Istanbul/Kusadasi (* Turkey) & Rosa-Jiménez et al. (2018) & 1 \\
\hline Tokyo (Japan) & Hein (2014) & 1 \\
\hline Kawasaki (Japan) & Fusco Girard and Nocca (2019) & 1 \\
\hline Kanazawa (Japan) & Mammadova (2017) & 1 \\
\hline Kushiro (Japan) & Ito et al. (2019) & 1 \\
\hline Incheon (Korea) & Lee et al. (2019), Kwon et al. (2019) & 2 \\
\hline Jakarta (Indonesia) & Younger et al. (2015) & 1 \\
\hline Famagusta (Cyprus) & Gurpinar and Balcioglu (2018) & 1 \\
\hline $\begin{array}{l}\text { Istanbul (Turkey), Shanghai (China), } \\
\text { Ho Chi Minh City (Vietnam) }\end{array}$ & Schipper et al. (2017) & 1 \\
\hline $\begin{array}{l}\text { Shanghai et al. (China), Singapore (Singapore), Busan } \\
\text { (South Korea), Dubai (United Arab Emirates), Klang et al. } \\
\text { (Malaysia), Kaohsiung (Taiwan), Laem Chabang (Thailand) }\end{array}$ & Chen and Lam (2018) & 1 \\
\hline
\end{tabular}


Table 4. Cont.

\begin{tabular}{|c|c|c|}
\hline Port City (Country or Region) & Articles (Totally Selected 61 Articles) & Frequency $(\%)$ \\
\hline No specified port city (* Turkey, India, Japan) & Yigit and Acarkan (2018) & 1 \\
\hline America & & $9(15 \%)$ \\
\hline Los Angeles et al. (USA) & De Lara (2017) & 1 \\
\hline Los Angeles (USA) & Chen and Lam (2018) & 1 \\
\hline Seattle (USA) & Wessells (2014) & 1 \\
\hline Philadelphia (USA) & Hein (2014) & 1 \\
\hline Halifax et al. (Canada) & Hoyle (1999) & 1 \\
\hline Rio de Janeiro (Brazil) & Morel et al. (2013) & 1 \\
\hline Santos (Brazil) & Zanetti et al. (2016) & 1 \\
\hline Los Angeles (USA), Valparaiso (Chile) & Schipper et al. (2017) & 1 \\
\hline No specified port city (Brazil) & Yigit and Acarkan (2018) & 1 \\
\hline Africa & & $5(8 \%)$ \\
\hline Suez Canal et al. (Egypt) & Ezzat (2016) & 1 \\
\hline Port Said (Egypt) & Megahed (2014) & 1 \\
\hline Elizabeth (South Africa) & Odindi and Mhangara (2012) & 1 \\
\hline Dar Es Salaam (Tanzania) & Schipper et al. (2017) & 1 \\
\hline Tunis (The Republic of Tunisia) & Rosa-Jiménez et al. (2018) & 1 \\
\hline Oceania & & $3(5 \%)$ \\
\hline Melbourne (Australia) & Schipper et al. (2017) & 1 \\
\hline Suva et al. (Fiji) & Gravelle and Mimura (2008) & 1 \\
\hline $\begin{array}{l}\text { Honiara (Solomon Islands), Port Vila } \\
\text { (The Republic of Vanuatu) }\end{array}$ & Trundle et al. (2019) & 1 \\
\hline No specified country or region & $\begin{array}{l}\text { Fusco Girard (2013), Fusco Girard (2010), } \\
\text { Przybyłowski (2019), Ignaccolo et al. (2018) }\end{array}$ & $4(7 \%)$ \\
\hline
\end{tabular}

\subsubsection{Research Focuses}

After examining the research focus of each article, we grouped the 61 articles into five research-focus categories (Table 5).

Focus 1: the impact of ports' and cities' interactions on the sustainability of port cities

Ports and cities are two different spatial economies, and they are always in a dynamic state of interaction and interdependence. In port-city interactions, the port benefits the city by its role in facilitating trade, employment, economic development, and environmental sustainability, while the port relies on the city to obtain services, including the labour pool and management talent [42]. Considering sustainability, creativity and resilience, ports could become development opportunities for port cities [43]. Protecting the architectural heritage of ports could help improve the quality of life for local residents, and could promote the sustainable social development of port cities [44]. The efficiency of the port would affect the economic development of port cities [45]. The environment and sustainability plans of ports could guide the ecological sustainability of port cities in some ways [46]. The wealth growth for port cities is a balance between ports and cities adapting to shifting needs and opportunities [47]. Xiao and Lam [10] used the system theory to develop a system framework for the sustainable development of port cities, based on economic, social and environmental standards, in order to analyze the relationship between the port and city of Singapore. Liu et al. [48] used a grey relative relational model and a coupling coordination degree model to analyze the degree of interaction and the coordination trends between the comprehensive development levels of port cities. 
The analysis of Li et al. [49] showed that the increase in maritime transportation activities promoted urban economic growth to a certain extent, but also brought environmental pollution and waste of resources. It was necessary to adopt energy-saving and emission-reduction measures to realize the green development of ports and cities. The study from Pugliano et al. [50] showed that only through the integration of urban and port planning, and through a balance between public and private interests, could the sustainable development of port cities truly be realized.

Focus 2: the evaluation of the sustainable performance (plans, policies and programs) of port cities. With the focus on sustainability and the deepening of sustainable practices for port cities, people have begun to pay attention to the implementation effects of sustainable plans or policies for port cities. Assessing sustainability performance or establishing evaluation standards are complex tasks involving multiple factors and various quantitative indicators [30]. Chen and Lam [51] applied a two-stage Data Envelopment Analysis (DEA) approach to measure and compare the sustainability efficiency of 20 world-leading container port cities. Schipper et al. [52] applied a series of social, economic and environmental key performance indicators (KPIs) to evaluate the development level of sustainable ports and cities. Cavallo et al. [53] used the Analytic Hierarchy Process (AHP) to evaluate and make decisions on the sustainable development proposal for the port city of Naples. Attardi et al. [54] took a Strategic Environmental Assessment (SEA) approach to conduct an environmental assessment of Taranto and Brindisi, two industrial port cities in Italy. Wang et al. [55] evaluated the ecological impact of development policy for port cities. Mrak [56] created decision-aid tools to evaluate the sustainability of the development plans for a port region. The circular city is becoming a new practice for sustainable urban development. Some researchers proposed an evaluation index system for the circular city [57,58]. Others [59] applied the concept of the circular city to the practice of the recycling seaport, and evaluated its performance.

Focus 3: the impact of stakeholders on the sustainability of port cities

'Stakeholders' refers to people, organizations or groups that have obvious interests or influence on the policies adopted. There are four groups of port city stakeholders: internal stakeholders, the public sector, market players/corporate bodies, and community/interest groups. 'Internal stakeholders' mainly refers to port employees, managers, owners and supervisors, etc.; 'public sector stakeholders' mainly refers to port authorities, national governments and relevant departments, etc.; 'market players/corporate bodies' mainly refers to stakeholder organizations, such as shipowners, transportation companies and logistics companies, etc.; community/interest groups mainly refer to local residents living near the port, consumers and taxpayers, and non-profit organizations. For the sustainability of port cities, it is important to identify the key stakeholders and the goals they seek, in order to reasonably balance the relationship between economic, social, and environmental performance for port cities [9]. Ignaccolo et al. [60] believed that the participation of stakeholders in sustainable port planning was conducive to the common sustainable development of port communities and ports. Bossuyt and Savini [61] studied the role of political parties in formulating sustainable urban policies. Hoyle [62] explored the degree and the nature of the influence of community groups on the changing processes and patterns of the urban waterfront. Frantzeskaki et al. [63] studied the role of partnerships in sustainable urban governance. De Lara [64] studied the ways in which the policymakers of the cities of Long Beach and Los Angeles in the United States incorporated racial, environmental, and class instability into the region's ecological structure, in order to resolve racial and class differences among the port workers.

Focus 4: the problems facing the sustainable development of port cities

Natural disasters such as rising sea levels, tsunamis, and beach erosion caused by human factors has affected the sustainable development of some port cities [65-69]. The air pollution and traffic congestion caused by port production and operation activities has affected the air quality of port cities and the quality of life of their residents [70-72]. The development of cruises and tourism has increased air pollution and traffic congestion in port cities [73-75]. In some port cities, the intensity of the land expansion in the port area was higher than that of the entire central city, which was not conducive to 
the expansion of the urban living space and public living space, and thus affected the quality of the human settlements [76].

Focus 5: technologies, methods and measures to promote the sustainability of port cities

In port cities, the endogenous climate resilience [77] and new smart technologies [78] could be used to deal with climate change and to manage water. Yigit and Acarkan [79] proposed a new power management method and algorithm for ships using hybrid energy in ports. Odindi and Mhangara [80] suggested the use of remote sensing technology to monitor the trend of green space in the city of Port Elizabeth, in order to optimize the social environment and the natural functions. Van Timmeren et al. [81] believed that optimizing the energy balance and using renewable energy could promote sustainable port city regeneration.

The use of interactive visual support tools [82] and the Historical Urban Landscape (HUL) approach $[27,83]$ could help develop the port area into a hot spot for the sustainable development of port cities, and could realize the smart and sustainable development of port cities. Ravetz [84] suggested that the "synergistic mapping" approach had played a role in the sustainable economic development of port cities. The application of circular economy methods in ports generated a large amount of waste value-added, and promoted the sustainable development of port cities [7,85]. The PHEBUS(it is a multidisciplinary research team) research group helped port cities to design, evaluate, compare and select solutions for future sustainable development by using thematic research and integrated system approaches [86].

Improving the traffic management policy or infrastructure of port cities [87] and implementing sustainable urban mobility planning [88] would help to reduce port emissions and traffic congestion, and would respond to the challenges of sustainable development for port cities [89]. The development of an integrated modelling-measurement system for the near-real-time assessment of port activities on air pollution could strengthen port pollution management and improve the air quality in port cities [90]. The use of the urban growth boundary (UGB) delimitation method [91], the implementation of integrated territorial investments (ITI) [92], the improvement of the utilization efficiency of urban land [93], and the designing of urban blue space [94] could promote the sustainability of the ecological environment of port cities. Using material flow analysis (MFA) to analyze the urban metabolism (UM) was conducive to resource management and supported the sustainable environmental planning of port cities [95]. The implementation of a smart urban metabolism (SUM) could support the sustainable development of port cities [96]. Different departments of the city have operated in an integrated manner to achieve sustainable development, which played an important role in the sustainability of port cities [97]. Meyer et al. [98] proposed that the sustainable development of Rotterdam must establish links between strategies, projects and participants. Van Tuijl and van den Berg [5] believed that a great social value could be produced for Rotterdam by holding an annual city festival-World Port Day (WPD) - to show citizens the port and its related industrial activities.

Table 5. Classification according to research focus categories.

\begin{tabular}{|c|c|c|c|}
\hline $\begin{array}{l}\text { Research Focus } \\
\text { Categories }\end{array}$ & Articles (Totally Selected 61 Articles) & Frequency & Percent \\
\hline $\begin{array}{l}\text { Focus 1: The impact of } \\
\text { ports and cities interaction } \\
\text { on sustainability of } \\
\text { port cities }\end{array}$ & $\begin{array}{c}\text { Fusco Girard (2010), Megahed (2014), Gurpinar and } \\
\text { Balcioglu (2018), Holmstedt et al. (2017), Hein (2014), } \\
\text { Liu et al. (2019), Li et al. (2019), Pugliano et al. (2018), } \\
\text { Xiao and Lam (2017) }\end{array}$ & 9 & $15 \%$ \\
\hline $\begin{array}{l}\text { Focus 2: The evaluation of } \\
\text { sustainable performance } \\
\text { (plans, policies and } \\
\text { programs) with port cities }\end{array}$ & $\begin{array}{l}\text { Chen and Lam (2018), Schipper et al. (2017), } \\
\text { Attardi et al. (2012), Cavallo et al. (2015), Wang et al. } \\
\text { (2009), Mrak (2013), Fusco Girard and Nocca (2019), } \\
\text { Gravagnuolo et al. (2019), Williams (2019) }\end{array}$ & 9 & $15 \%$ \\
\hline $\begin{array}{l}\text { Focus 3: The impact of } \\
\text { stakeholders on } \\
\text { sustainability of port cities }\end{array}$ & $\begin{array}{c}\text { Lam and Yap (2019), Ignaccolo et al. (2018), Bossuyt } \\
\text { and Savini (2018), Hoyle (1999), Frantzeskaki et al. } \\
\text { (2014), De Lara (2017) }\end{array}$ & 6 & $10 \%$ \\
\hline
\end{tabular}


Table 5. Cont.

\begin{tabular}{|c|c|c|c|}
\hline Research Focus Categories & Articles (Totally Selected 61 Articles) & Frequency & Percent \\
\hline $\begin{array}{l}\text { Focus 4: The problems } \\
\text { facing the sustainable } \\
\text { development of port cities }\end{array}$ & $\begin{array}{l}\text { Sheeran and Pilato (2017), Ito et al. (2019), Gravelle and } \\
\text { Mimura (2008), Zanetti et al. (2016), Aragonés et al. (2017), } \\
\text { Kwon et al. (2019), Lee et al. (2019), Younger et al. (2015), } \\
\text { Ruiz-Guerra et al. (2019), Rosa-Jiménez et al. (2018), } \\
\text { Dundović et al. (2013), Zheng Wang et al. (2017) }\end{array}$ & 12 & $20 \%$ \\
\hline $\begin{array}{l}\text { Focus 5: Technologies, } \\
\text { methods and measures to } \\
\text { promote sustainability of } \\
\text { port cities }\end{array}$ & $\begin{array}{c}\text { Meyer et al. (2012), Karimpour et al. (2019), van Tuijl and } \\
\text { van den Berg (2016), Yigit and Acarkan (2018), Ezzat (2016), } \\
\text { Fusco Girard (2013), Morel et al. (2013), Odindi and Mhangara } \\
\text { (2012), Ravetz (2014), Trundle et al. (2019), Dircke and } \\
\text { Molenaar (2010), Van Timmeren et al. (2012), Kourtit and } \\
\text { Nijkamp (2013), De Rosa and Di Palma (2013), Tang et al. } \\
\text { (2017), Przybyłowski (2018), Przybyłowski (2019), Merico et al. } \\
\text { (2019), Zheng, Yang et al. (2017), Delitheou and } \\
\text { Georgakopoulou (2019), Li et al. (2016), Wessells (2014), } \\
\text { Voskamp et al. (2017), Shahrokni et al. (2015), } \\
\text { Mammadova (2017) }\end{array}$ & 25 & $41 \%$ \\
\hline Total & & 61 & $101 \%$ \\
\hline
\end{tabular}

\subsubsection{Research Methods}

According to the methods and means of the research design and data acquisition, the research methods can be divided into qualitative research and quantitative research [31]. Qualitative research is based on textual descriptions or explanations, and the field study, historical comparison and other methods are often used. Quantitative research is based on data analysis, the methods such as experiments and surveys are often used. Of the 61 articles, $51 \%$ of the articles adopted qualitative research, $38 \%$ of the articles adopted quantitative research, and $11 \%$ of the articles adopted both qualitative and quantitative research (Table 6).

Table 6. Distribution of the research methods in the articles.

\begin{tabular}{|c|c|c|c|}
\hline Research Methods Of Study & Articles (Totally Selected 61 Articles) & Frequency & Percent \\
\hline Qualitative Study & $\begin{array}{l}\text { Fusco Girard (2013), Morel et al. (2013), De Lara (2017), Xiao } \\
\text { and Lam (2017), Ezzat (2016), Hoyle (1999), Meyer et al. (2012), } \\
\text { Frantzeskaki et al. (2014), Hein (2014), Ravetz (2014), } \\
\text { Pugliano et al. (2018), Attardi et al. (2012), van Tuijl and } \\
\text { van den Berg (2016), Gravagnuolo et al. (2019), Williams } \\
\text { (2019), Bossuyt and Savini (2018), Przybyłowski (2019), } \\
\text { Sheeran and Pilato (2017), Mammadova (2017), } \\
\text { Holmstedt et al. (2017), Wessells (2014), Dundović et al. (2013), } \\
\text { Dircke and Molenaar (2010), Megahed (2014), } \\
\text { Van Timmeren et al. (2012), Aragonés et al. (2017), Fusco } \\
\text { Girard (2010), Ignaccolo et al. (2018), Younger et al. (2015), } \\
\text { Trundle et al. (2019), Przybyłowski (2018) }\end{array}$ & 31 & $51 \%$ \\
\hline Quantitative Study & $\begin{array}{l}\text { Schipper et al. (2017), Chen and Lam (2018), Yigit and } \\
\text { Acarkan (2018), Cavallo et al. (2015), Liu et al. (2019), Odindi } \\
\text { and Mhangara (2012), Li et al. (2019), Fusco Girard and Nocca } \\
\text { (2019), Lee et al. (2019), Merico et al. (2019), Ruiz-Guerra et al. } \\
\text { (2019), Ito et al. (2019), Rosa-Jiménez et al. (2018), Zheng, } \\
\text { Yang et al. (2017), Zheng, Wang et al. (2017), Tang et al. (2017), } \\
\text { Voskamp et al. (2017), Wang et al. (2009), Gurpinar and } \\
\text { Balcioglu (2018), Li et al. (2016), Zanetti et al. (2016), Gravelle } \\
\text { and Mimura (2008), Kwon et al. (2019) }\end{array}$ & 23 & $38 \%$ \\
\hline $\begin{array}{l}\text { Qualitative and Quantitative } \\
\text { Study }\end{array}$ & $\begin{array}{l}\text { Kourtit and Nijkamp (2013), Lam and Yap (2019), De Rosa and } \\
\text { Di Palma (2013), Karimpour et al. (2019), Shahrokni et al. } \\
\text { (2015), Delitheou and Georgakopoulou (2019), Mrak (2013) }\end{array}$ & 7 & $11 \%$ \\
\hline Total & & 61 & $100 \%$ \\
\hline
\end{tabular}




\section{Conclusions and Future Research}

\subsection{The Main Findings of the Research}

Port sustainability has been become an increasingly important research topic during the past ten years. From the perspective of geographic research areas, European port cities are the hot spots for sustainability research. Regarding research fields, technologies, methods and measures to promote the sustainability of port cities are popular research topics. In terms of research methods, qualitative research plays an important role in the study of port city sustainability.

\subsection{Future Research Directions}

We suggest that the future research on port city sustainability should follow five directions:

(1) Expanding the regional scope of the case study.

According to the latest list of the world's top 100 container ports released by Lloyd's Daily, in the UK, the top ten container ports are all in Asia, and seven of them are in China [99]. Port cities face different challenges between Europe and Asia. In Europe, due to the low interdependence and relatively stable relationships between ports and cities, the functions of ports and cities were separated earlier, and most of the waterfront areas were redeveloped because of their long history and rich cultural resources. In Asia, ports and cities have developed in a symbiotic manner, and the interdependence between ports and cities is strong, and is in a downward trend [100]. In Africa, there is huge economic potential, and great space for the development of ports and port cities. Due to the different relationships between ports and cities among different regions, the problems faced by the sustainable development of port cities are also different. One port city can learn from another's experiences, but cannot copy them. Therefore, it will be helpful to conduct additional case studies focusing on differences in port cities between Asia, Africa and South America in the future.

(2) Enriching the assessment content for the sustainable performance (plans, policies and programs) of port cities.

As shown in Table 5, there are only nine articles related to the assessment of sustainable performance (plans, policies and programs) for ports and port cities, mainly using environmental, economic and social sustainability indicators. The content of environmental assessment mostly focuses only on the impact of the port's activities and infrastructure on the natural (urban) system, but rarely involves the risk assessment. On 4 August 2020, an explosion occurred at a dangerous goods warehouse in Port Beirut, Lebanon. At least 200 people were killed, and about 5000 were injured. A large number of buildings near the port were destroyed. As many as 300,000 people were temporarily homeless, and the damage could reach $\$ 10-15$ billion [101]. On 12 August 2015, a large explosion occurred in a dangerous goods warehouse in Tianjin Port, China. About 173 people were killed, a large number of buildings and containers were destroyed, and economic losses of $\$ 1.1$ billon were caused [102]. In view of the staggering damage caused to port cities by the occurrence of port accidents, it is necessary to strengthen the risk assessment of ports and port cities in the future.

(3) Paying attention to the application of clean energy technologies in sustainable ports and port cities.

Clean energy sources, such as wind energy, solar energy, wave energy, and renewable energy are continuing to change the world. The development of clean energy technologies provides a broad prospect for the reduction of pollution in ports and port cities. Paying attention to the research and application of clean energy technologies in the sustainable development of ports and port cities is a future development trend.

(4) Promoting artificial intelligence in sustainable ports and port cities.

In recent years, artificial intelligence (AI) technology has developed rapidly, and has attracted the attention of many countries and regions for the promotion of sustainable development goals. In terms of environmental sustainability, machine learning and computational simulations can help port cities to recognize climate changes and take actions. AI can be used to monitor environmental damage, and to 
provide early warning of major events in ports and port cities. In terms of social sustainability, AI can excavate port cultural heritage, which is beneficial for port cities in that it allows them to promote the harmonious development of society, the economy and the environment, while protecting ports' cultural heritage.

(5) Applying landsenses ecology in sustainable ports and port cities.

There are many ports in the world which often have rich tangible and intangible cultural values due to their long history. It is of great significance for the port city system to transform the urban port landscape into a sustainable and creative hot spot while protecting the ports' cultural heritage. The strengthening of the planning of ports and port cities is hugely important. Landsenses ecology is based on ecological principles and the analysis framework of natural elements, physical senses, psychological perceptions, socioeconomic perspectives, process-risk, and so on, and is closely linked with ecosystem services and sustainable development through landsense creation [103]. In the future, will be important to promote the application of landsenses ecology in the renewal of ports and port cities. Whilst it protects the coastal ecosystem and the historical and cultural heritage of ports, it also mobilizes people's physical and psychological perceptions, creates the port's image, stimulates the economy while meeting social needs, and realizes the regeneration and sustainable development of port cities.

Author Contributions: Conceptualization, Y.Z.; Project administration, J.Z.; Methodology, G.S. All authors have read and agreed to the published version of the manuscript.

Funding: This research received no external funding.

Acknowledgments: This research was supported by the Training Program of Fujian Excellent Talents in University (FETU). The authors thank Ziheng $\mathrm{Xu}$ for improving the writing of this manuscript.

Conflicts of Interest: The authors declare no conflict of interest.

\section{References}

1. World Commission on Environment and Development (WCED). Available online: http://www.un-documents. net/wced-ocf.htm (accessed on 15 March 2020).

2. Glavič, P.; Lukman, R. Review of sustainability terms and their definitions. J. Clean. Prod. 2007, 15, 1875-1885. [CrossRef]

3. Anand, S.; Sen, A. Human development and economic sustainability. World Dev. 2000, 28, 2029-2049. [CrossRef]

4. Littig, B.; Griessler, E. Social sustainability: A catchword between political pragmatism and social theory. Int. J. Sustain. Dev. 2005, 8, 65-79. [CrossRef]

5. van Tuijl, E.; van den Berg, L. Annual city festivals as tools for sustainable competitiveness: The World Port Days Rotterdam. Economies 2016, 4, 11. [CrossRef]

6. Zhao, J.; Zhu, Y.G.; Shao, G.; Ness, D. Coping with an urbanising world: Interdisciplinary research towards sustainability. Int. J. Sustain. Dev. World Ecol. 2008, 15, 284-287.

7. Karimpour, R.; Ballini, F.; Ölcer, A.I. Circular economy approach to facilitate the transition of the port cities into self-sustainable energy ports-A case study in Copenhagen-Malmö Port (CMP). Wmu J. Marit. Aff. 2019, 18, 225-247. [CrossRef]

8. The Mori Memorial Foundation-Institute for Urban Strategies. Available online: http://mori-m-foundation. or.jp/english/ius2/gpci2/index.shtml (accessed on 10 September 2020).

9. Lam, J.S.L.; Yap, W.Y. A stakeholder perspective of port city sustainable development. Sustainability 2019, 11, 447. [CrossRef]

10. Xiao, Z.; Lam, J.S.L. A systems framework for the sustainable development of a Port City: A case study of Singapore's policies. Res. Transp. Bus. Manag. 2017, 22, 255-262. [CrossRef]

11. Nebot, N.; Rosa-Jiménez, C.; Ninot, R.P.; Perea-Medina, B. Challenges for the future of ports. What can be learnt from the Spanish Mediterranean ports? Ocean Coast. Manag. 2017, 137, 165-174. [CrossRef]

12. Shao, J.; Qiu, Q.; Qian, Y.; Tang, L. Optimal visual perception in land-use planning and design based on landsenses ecology. Int. J. Sustain. Dev. World Ecol. 2020, 27, 233-239. [CrossRef] 
13. International Chamber of Shipping. Available online: http://www.shipping-facts.com (accessed on 25 April 2020).

14. Christodoulou, A.; Kappelin, H. Determinant factors for the development of maritime supply chains: The case of the Swedish forest industry. Case Stud. Transp. Policy 2020, 8, 711-720. [CrossRef]

15. Lu, C.S.; Shang, K.C.; Lin, C.C. Examining sustainability performance at ports: Port managers' perspectives on developing sustainable supply chains. Marit. Policy Manag. 2016, 43, 909-927. [CrossRef]

16. Carpenter, A.; Lozano, R.; Sammalisto, K.; Astner, L. Securing a port's future through Circular Economy: Experiences from the Port of Gavle in contributing to sustainability. Mar. Pollut. Bull. 2018, 128, 539-547. [CrossRef] [PubMed]

17. Žgaljić, D.; Tijan, E.; Jugović, A.; Poletan Jugović, T. Implementation of sustainable motorways of the sea services multi-criteria analysis of a Croatian port pystem. Sustainability 2019, 11, 6827. [CrossRef]

18. De Boer, W.P.; Slinger, J.H.; Vreugdenhil, H.S.; Taneja, P. Identifying ecosystem-based alternatives for the design of a seaport's marine infrastructure: The case of Tema port expansion in Ghana. Sustainability 2019, 11, 6633. [CrossRef]

19. Cao, M.; Duan, X.; Zhao, X. Construction of integrated evaluation system for green port construction based on BIM technology. J. Coast. Res. 2019, 93, 1073-1079. [CrossRef]

20. Winnes, H.; Styhre, L.; Fridell, E. Reducing GHG emissions from ships in port areas. Res. Transp. Bus. Manag. 2015, 17, 73-82. [CrossRef]

21. Chen, J.; Huang, T.; Xie, X.; Lee, P.T.W.; Hua, C. Constructing governance framework of a green and smart port. J. Mar. Sci. Eng. 2019, 7, 83. [CrossRef]

22. Kontovas, C.; Psaraftis, H.N. Reduction of emissions along the maritime intermodal container chain: Operational models and policies. Marit. Policy Manag. 2011, 38, 451-469. [CrossRef]

23. Lam, J.S.L.; Notteboom, T. The greening of ports: A comparison of port management tools used by leading ports in Asia and Europe. Transp. Rev. 2014, 34, 169-189. [CrossRef]

24. Puig, M.; Wooldridge, C.; Casal, J.; Darbra, R.M. Tool for the identification and assessment of Environmental Aspects in Ports (TEAP). Ocean Coast. Manag. 2015, 113, 8-17. [CrossRef]

25. Lirn, T.C.; Jim Wu, Y.C.; Chen, Y.J. Green performance criteria for sustainable ports in Asia. Int. J. Phys. Distrib. Logist. Manag. 2013, 43, 427-451. [CrossRef]

26. López-Navarro, M.Á.; Tortosa-Edo, V.; Llorens-Monzonís, J. Environmental management systems and local community perceptions: The case of petrochemical complexes located in ports. Bus. Strategy Environ. 2015, 24, 236-251. [CrossRef]

27. Fusco Girard, L. Toward a smart sustainable development of port cities/areas: The role of the "Historic Urban Landscape" approach. Sustainability 2013, 5, 4329-4348. [CrossRef]

28. Christodoulou, A.; Cullinane, K. Identifying the main opportunities and challenges from the implementation of a port energy management system: A SWOT/PESTLE analysis. Sustainability 2019, 11, 6046. [CrossRef]

29. Sislian, L.; Jaegler, A.; Cariou, P. A literature review on port sustainability and ocean's carrier network problem. Res. Transp. Bus. Manag. 2016, 19, 19-26. [CrossRef]

30. Lim, S.; Pettit, S.; Abouarghoub, W.; Beresford, A. Port sustainability and performance: A systematic literature review. Transp. Res. Part D: Transp. Environ. 2019, 72, 47-64. [CrossRef]

31. Özispa, N.; Arabelen, G. Sustainability issues in ports: Content analysis and review of the literature (1987-2017). Shs Web Conf. 2018, 58, 01022. [CrossRef]

32. Hakam, M.H.; Solvang, W.D. Container ports sustainability-a literature review. In Proceedings of the 2013 IEEE 4th International Conference on Cognitive Infocommunications (CogInfoCom), Budapest, Hungary, 2-5 December 2013; IEEE: Budapest, Hungary, 2013; pp. 803-810.

33. Krippendorff, K. Content analysis. In International Encyclopedia of Communication; Barnouw, E., Gerbner, G., Schramm, W., Worth, T.L., Gross, L., Eds.; Oxford University Press: New York, NY, USA, 1989; pp. $403-407$.

34. White, M.D.; Marsh, E.E. Content analysis: A flexible methodology. Libr. Trends 2006, 55, 22-45. [CrossRef]

35. Seuring, S.; Wilding, R.; Gold, S. Conducting content-analysis based literature reviews in supply chain management. Supply Chain Manag. Int. J. 2012, 17, 544-555. [CrossRef]

36. Hsieh, H.F.; Shannon, S.E. Three approaches to qualitative content analysis. Qual. Health Res. 2005, 15, 1277-1288. [CrossRef] [PubMed]

37. Davarzani, H.; Fahimnia, B.; Bell, M.; Sarkis, J. Greening ports and maritime logistics: A review. Transp. Res. Part D Transp. Environ. 2016, 48, 473-487. [CrossRef] 
38. Ashrafi, M.; Walker, T.R.; Magnan, G.M.; Adams, M.; Acciaro, M. A review of corporate sustainability drivers in maritime ports: A multi-stakeholder perspective. Marit. Policy Manag. 2020, 1-18. [CrossRef]

39. Gu, Q.; Lago, P. Exploring service-oriented system engineering challenges: A systematic literature review. Serv. Oriented Comput. Appl. 2009, 3, 171-188. [CrossRef]

40. Badurina, P.; Cukrov, M.; Dundović, Č. Contribution to the implementation of "Green Port" concept in Croatian seaports. Pomorstvo 2017, 31, 10-17. [CrossRef]

41. Lam, J.S.L.; Gu, Y. Port hinterland intermodal container flow optimisation with green concerns: A literature review and research agenda. Int. J. Shipp. Transp. Logist. 2013, 5, 257-281. [CrossRef]

42. Yap, W.Y. The Port and the City, in Business and Economics of Port Management: An Insider's Perspective; Routledge: Abingdon, UK, 2020; pp. 259-277.

43. Fusco Girard, L. Sustainability, creativity, resilience: Toward new development strategies of port areas through evaluation processes. Int. J. Sustain. Dev. 2010, 13, 161-184. [CrossRef]

44. Megahed, N. Heritage-based sustainability in Port Said: Classification of styles and future development. Int. J. Archit. Res. Archnet-Ijar 2014, 8, 94-107. [CrossRef]

45. Gurpinar, N.; Balcioglu, H.B. Impact of Famagusta port efficiency on north Cyprus economic development. Rev. De Cercet. Si Interv. Soc. 2018, 60, 143-156.

46. Holmstedt, L.; Brandt, N.; Robert, K.H. Can Stockholm Royal Seaport be part of the puzzle towards global sustainability? -From local to global sustainability using the same set of criteria. J. Clean. Prod. 2017, 140, 72-80.

47. Hein, C. Port cities and urban wealth: Between global networks and local transformations. Int. J. Glob. Environ. Issues 2014, 13, 339-361. [CrossRef]

48. Liu, J.; Zhou, J.; Liu, F.; Yue, X.; Kong, Y.; Wang, X. Interaction analysis and sustainable development strategy between port and city: The case of Liaoning. Sustainability 2019, 11, 5366. [CrossRef]

49. Li, Y.; Zhang, X.; Lin, K.; Huang, Q. The analysis of a simulation of a port-city green cooperative development, based on system dynamics: A case study of Shanghai Port, China. Sustainability 2019, 11, 5948. [CrossRef]

50. Pugliano, G.; Benassai, G.; Benassai, E. Integrating urban and port planning policies in a sustainable perspective: The case study of Naples historic harbour area. Plan. Perspect. 2018, 34, 827-847. [CrossRef]

51. Chen, C.; Lam, J.S.L. Sustainability and interactivity between cities and ports: A two-stage data envelopment analysis (DEA) approach. Marit. Policy Manag. 2018, 45, 944-961. [CrossRef]

52. Schipper, C.A.; Vreugdenhil, H.; De Jong, M.P.C. A sustainability assessment of ports and port-city plans: Comparing ambitions with achievements. Transp. Res. Part D Transp. Environ. 2017, 57, 84-111. [CrossRef]

53. Cavallo, B.; D'Apuzzo, L.; Squillante, M. A multi-criteria decision making method for sustainable development of Naples port city-area. Qual. Quant. 2015, 49, 1647-1659. [CrossRef]

54. Attardi, R.; Bonifazi, A.; Torre, C.M. Evaluating sustainability and democracy in the development of industrial port cities: Some Italian cases. Sustainability 2012, 4, 3042-3065. [CrossRef]

55. Wang, S.; Li, J.; Wu, D.; Liu, J.; Zhang, K.; Wang, R. The strategic ecological impact assessment of urban development policies: A case study of Rizhao City, China. Stoch. Environ. Res. Risk Assess. 2009, 23, 1169-1180. [CrossRef]

56. Mrak, I. Locally based development-tools for identifying opportunities and evaluating port area strategies of Rijeka. Sustainability 2013, 5, 4024-4056. [CrossRef]

57. Fusco Girard, L.; Nocca, F. Moving towards the circular economy/city model: Which tools for operationalizing this model? Sustainability 2019, 11, 6253. [CrossRef]

58. Gravagnuolo, A.; Angrisano, M.; Fusco Girard, L. Circular economy strategies in eight historic port cities: Criteria and indicators towards a circular city assessment framework. Sustainability 2019, 11, 3512. [CrossRef]

59. Williams, J. The circular regeneration of a seaport. Sustainability 2019, 11, 3424. [CrossRef]

60. Ignaccolo, M.; Inturri, G.; Le Pira, M. Framing stakeholder involvement in sustainable port planning. Trans. Marit. Sci. 2018, 7, 136-142. [CrossRef]

61. Bossuyt, D.M.; Savini, F. Urban sustainability and political parties: Eco-development in Stockholm and Amsterdam. Environ. Plan. C Politics Space 2018, 36, 1006-1026. [CrossRef]

62. Hoyle, B. Scale and sustainability: The role of community groups in Canadian port-city waterfront change. J. Transp. Geogr. 1999, 7, 65-78. [CrossRef]

63. Frantzeskaki, N.; Wittmayer, J.; Loorbach, D. The role of partnerships in 'realising' urban sustainability in Rotterdam's City Ports Area, the Netherlands. J. Clean. Prod. 2014, 65, 406-417. [CrossRef] 
64. De Lara, J. "This port is killing people": Sustainability without justice in the Neo-Keynesian green city. Ann. Am. Assoc. Geogr. 2017, 108, 538-548. [CrossRef]

65. Sheeran, P.; Pilato, M. The fall and rise of Venice as a sea port marine management, sustainability, and the economics of heritage1. Calitatea 2017, 18, 416-418.

66. Ito, T.; Setoguchi, T.; Miyauchi, T.; Ishii, A.; Watanabe, N. Sustainable downtown development for the tsunami-prepared urban revitalization of regional coastal cities. Sustainability 2019, 11, 1020. [CrossRef]

67. Gravelle, G.; Mimura, N. Vulnerability assessment of sea-level rise in Viti Levu, Fiji Islands. Sustain. Sci. 2008, 3, 171-180. [CrossRef]

68. Zanetti, V.B.; de Sousa, W.C.; De Freitas, D.M. A climate change vulnerability index and case study in a Brazilian coastal city. Sustainability 2016, 8, 811. [CrossRef]

69. Aragonés, L.; Garcia-Barba, J.; Villacampa, Y.; López Úbeda, I.; Gómez-Martín, M.E.; Pagán, J.I. Sustainable development city-beach in Alicante. Int. J. Sustain. Dev. Plan. 2017, 12, 704-712. [CrossRef]

70. Kwon, Y.; Lim, H.; Lim, Y.; Lee, H. Implication of activity-based vessel emission to improve regional air inventory in a port area. Atmos. Environ. 2019, 203, 262-270. [CrossRef]

71. Lee, H.; Pham, H.T.; Kim, C.; Lee, K. A study on emissions from drayage trucks in the port city-focusing on the port of Incheon. Sustainability 2019, 11, 5358. [CrossRef]

72. Younger, J.S.; Parry, D.E.; Lubis, H.A.; McLernon, A.; Wignall, D.J.; Hasan, D.; Benton, G.G. Greater Jakarta, the world's second largest conurbation-Part 1. Proc. Inst. Civ. Eng. Munic. Eng. 2015, 168, 253-261.

73. Ruiz-Guerra, I.; Molina-Moreno, V.; Cortés-García, F.J.; Núñez-Cacho, P. Prediction of the impact on air quality of the cities receiving cruise tourism: The case of the Port of Barcelona. Heliyon 2019, 5, e01280. [CrossRef]

74. Rosa-Jiménez, C.; Perea-Medina, B.; Andrade, M.J.; Nebot, N. An examination of the territorial imbalance of the cruising activity in the main Mediterranean port destinations: Effects on sustainable transport. J. Transp. Geogr. 2018, 68, 94-101. [CrossRef]

75. Dundović, Č.; Jurić, M.; Kovačić, M. Optimizing the split port system to promote sustainable development. Pomorstvo 2013, 27, 285-298.

76. Zheng, Q.; Wang, K.; Huang, L.; Zheng, Q.; Abubakar, G.A. Monitoring the different types of urban construction land expansion (UCLE) in China's port city: A case study of Ningbo's central city. Sustainability 2017, 9, 2374. [CrossRef]

77. Trundle, A.; Barth, B.; McEvoy, D. Leveraging endogenous climate resilience: Urban adaptation in Pacific Small Island Developing States. Environ. Urban. 2019, 31, 53-74. [CrossRef]

78. Dircke, P.; Molenaar, A. Smart climate change adaptation in Rotterdam, delta city of the future. Water Pract. Technol. 2010, 5, wpt2010083. [CrossRef]

79. Yigit, K.; Acarkan, B. A new electrical energy management approach for ships using mixed energy sources to ensure sustainable port cities. Sustain. Cities Soc. 2018, 40, 126-135. [CrossRef]

80. Odindi, J.O.; Mhangara, P. Green spaces trends in the city of Port Elizabeth from 1990 to 2000 using remote sensing. Arch. Sid 2012, 6, 653-662.

81. Van Timmeren, A.; Zwetsloot, J.; Brezet, H.; Silvester, S. Sustainable urban regeneration based on energy balance. Sustainability 2012, 4, 1488-1509. [CrossRef]

82. Kourtit, K.; Nijkamp, P. The use of visual decision support tools in an interactive stakeholder analysis—old ports as new magnets for creative urban development. Sustainability 2013, 5, 4379-4405. [CrossRef]

83. De Rosa, F.; Di Palma, M. Historic urban landscape approach and port cities regeneration: Naples between identity and outlook. Sustainability 2013, 5, 4268-4287. [CrossRef]

84. Ravetz, J. Interconnected responses for interconnected problems: Synergistic pathways for sustainable wealth in port cities. Int. J. Glob. Environ. Issues 2014, 13, 362-388. [CrossRef]

85. Ezzat, A.M. Sustainable development of seaport cities through circular economy: A comparative study with implications to Suez Canal corridor project. Eur. J. Sustain. Dev. 2016, 5, 509-522. [CrossRef]

86. Morel, G.; Lima, F.R.; Martell-Flores, H.; Hissel, F. Tools for an integrated systems approach to sustainable port city planning. Urbe-Rev. Bras. De Gestão Urbana 2013, 5, 34-49. [CrossRef]

87. Tang, J.; McNabola, A.; Misstear, B.; Caulfield, B. An evaluation of the impact of the Dublin Port Tunnel and HGV management strategy on air pollution emissions. Transp. Res. Part D Transp. Environ. 2017, 52, 1-14. [CrossRef] 
88. Przybylowski, A. Sustainable urban mobility planning: Gdynia city case study. Ekonomia I Prawo. Econ. Law 2018, 17, 195-209.

89. Przybylowski, A. Global trends shaping life quality in agglomerations with particular emphasis on mobility in seaport agglomerations. Transnav-Int. J. Mar. Navig. Saf. Sea Transp. 2019, 13, 615-620. [CrossRef]

90. Merico, E.; Dinoi, A.; Contini, D. Development of an integrated modelling-measurement system for near-real-time estimates of harbour activity impact to atmospheric pollution in coastal cities. Transp. Res. Part D Transp. Environ. 2019, 73, 108-119. [CrossRef]

91. Zheng, Q.; Yang, X.; Wang, K.; Huang, L.; Shahtahmassebi, A.R.; Gan, M.; Weston, M.V. Delimiting urban growth boundary through combining land suitability evaluation and cellular automata. Sustainability 2017, 9, 2213. [CrossRef]

92. Delitheou, V.; Georgakopoulou, S. Integrated territorial investments as a tool for sustainable urban development. The case of Piraeus municipality. Theor. Empir. Res. Urban Manag. 2019, 14, $22-40$.

93. Li, M.; Zhang, Z.; Lo Seen, D.; Sun, J.; Zhao, X. Spatiotemporal characteristics of urban sprawl in Chinese port cities from 1979 to 2013. Sustainability 2016, 8, 1138. [CrossRef]

94. Wessells, A.T. Urban blue space and "the project of the century": Doing Justice on the Seattle waterfront and for local residents. Buildings 2014, 4, 764-784. [CrossRef]

95. Voskamp, I.M.; Stremke, S.; Spiller, M.; Perrotti, D.; van der Hoek, J.P.; Rijnaarts, H.H. Enhanced Performance of the Eurostat method for comprehensive assessment of urban metabolism: A material flow analysis of Amsterdam. J. Ind. Ecol. 2017, 21, 887-902. [CrossRef]

96. Shahrokni, H.; Årman, L.; Lazarevic, D.; Nilsson, A.; Brandt, N. Implementing smart urban metabolism in the Stockholm Royal Seaport: Smart city SRS. J. Ind. Ecol. 2015, 19, 917-929. [CrossRef]

97. Mammadova, A. Sustainability lessons from Kanazawa City, Japan. Eur. J. Sustain. Dev. 2017, 6, $233-239$. [CrossRef]

98. Meyer, H.; Nillesen, A.L.; Zonneveld, W. Rotterdam: A city and a mainport on the edge of a delta. Eur. Plan. Stud. 2012, 20, 71-94. [CrossRef]

99. Lloyd's List. Available online: https://lloydslist.maritimeintelligence.informa.com/one-hundred-containerports-2019 (accessed on 9 June 2020).

100. Ducruet, C. Port-city relationships in Europe and Asia. J. Int. Logist. Trade 2006, 4, 13-35. [CrossRef]

101. BBC NEWS. Available online: https://www.bbc.com/news/world-middle-east-53668493 (accessed on 9 June 2020).

102. BBC NEWS. Available online: https://www.bbc.com/news/world-asia-china-37927158 (accessed on 15 June 2020).

103. Zhao, J.; Yan, Y.; Deng, H.; Liu, G.; Dai, L.; Tang, L.; Shi, L.; Shao, G. Remarks about landsenses ecology and ecosystem services. Int. J. Sustain. Dev. World Ecol. 2020, 27, 196-201. [CrossRef] 